\title{
Effect of rumen-protected B vitamins and choline supplementation on health, production, and reproduction in transition dairy cows
}

\author{
E. I. Morrison, ${ }^{*}$ H. Reinhardt, ${ }^{*}$ H. Leclerc, $†$ T. J. DeVries, $\ddagger$ and S. J. LeBlanc ${ }^{\star 1}$ \\ *Department of Population Medicine, University of Guelph, Ontario, N1G 2W1 Canada \\ †Jefo, St. Hyacinthe, Quebec, J2S 7B6 Canada \\ ‡Department of Animal Biosciences, University of Guelph, Ontario, N1G 2W1 Canada
}

\begin{abstract}
The objectives were to determine the effects of a rumen-protected blend of $\mathrm{B}$ vitamins and choline (RPBC) on the incidence of health disorders, milk yield, and reproduction in early lactation and the effects on gene expression and liver fat infiltration. A randomized controlled trial in 3 commercial dairy herds $(\mathrm{n}=1,346$ cows with group as the experimental unit; experiment 1) and a university research herd $(\mathrm{n}=50$ cows with cow as the experimental unit; experiment 2) evaluated the use of $100 \mathrm{~g} /$ cow per d of commercially available proprietary RPBC supplement (Transition VB, Jefo, St. Hyacinthe, Quebec, Canada), or a placebo, fed 3 wk before to $3 \mathrm{wk}$ after calving. In experiment 2 liver biopsies were taken at 4 and $14 \pm 1 \mathrm{~d}$ in milk to measure triacylglycerol concentrations and expression of 28 genes selected to represent relevant aspects of liver metabolism. Treatment effects were assessed using multivariable mixed logistic regression models for binary health and reproductive outcomes; linear regression models for milk yield, dry matter intake, and liver outcomes; and survival analysis for time insemination and pregnancy. In experiment 1 , treatment did not have an effect on the incidence of hyperketonemia (blood $\beta$-hydroxybutyrate $\geq 1.2 \mathrm{mmol} / \mathrm{L}$; cumulative incidence to $3 \mathrm{wk}$ postpartum of 28 to $30 \%$ ), clinical health disorders, or udder edema. The prevalence of anovulation at $8 \mathrm{wk}$ postpartum was $11 \%$ in the treatment group and $23 \%$ in the control but did not differ statistically given group-level randomization. Pregnancy at first insemination (33 and $35 \%$ ) and median time to pregnancy to $200 \mathrm{~d}$ in milk (96 and $97 \mathrm{~d}$ ) were not different between treatment and control, respectively. No difference was observed between treatment groups in milk yield or components through the first 3 Dairy Herd Improvement Associa-
\end{abstract}

Received February 27, 2018.

Accepted June 25, 2018.

${ }^{1}$ Corresponding author: sleblanc@uoguelph.ca tion test days $(44 \mathrm{~kg} / \mathrm{d}$ in both groups, accounting for parity and components). In experiment 2 , there were no differences between treatment groups in feed intake. Mean blood $\beta$-hydroxybutyrate was lower at wk 3 in $\mathrm{RPBC}(0.6$ vs. $0.9 \pm 0.12 \mathrm{mmol} / \mathrm{L}$ ) with no difference between treatments for mean blood concentrations of fatty acids (wk -1 or 1 ) and $\beta$-hydroxybutyrate at wk 1 or 2 . The gene for acyl-CoA oxidase 1 (ACOX1) had lower mRNA abundance in RPBC with no difference between treatments for the other genes, but the expression of half of the genes assessed differed with days in milk. Liver triacylglycerol was lower in primiparous cows at $4 \mathrm{~d}$ in milk in RPBC (2.0 vs. $4.4 \pm 1.2 \%)$ but not at $14 \mathrm{~d}$ in milk (2.2 vs. $3.2 \pm 0.97 \%)$ with no treatment effect in multiparous cows $(4.6 \pm 0.8 \%)$. Accounting for parity, days in milk, fat and protein percentages, repeated test days, and a random effect of cow, no significant difference was observed between treatments in milk yield across the first 3 Dairy Herd Improvement Association tests $(41.2 \pm 1.3$ in RPBC vs. $38.0 \pm 1.4 \mathrm{~kg} / \mathrm{d}$ in control). Under the diet and management conditions of the field study including low prevalence of clinical health disorders, in experiment 1 we did not detect a benefit of RPBC, but in experiment 2 liver fat content decreased in primiparous cows.

Key words: hyperketonemia, ketosis, transition dairy cow, rumen-protected B vitamin, choline

\section{INTRODUCTION}

High-producing dairy cows are at high risk of developing metabolic diseases over the transition period (LeBlanc, 2010; Abuajamieh et al., 2016), defined as the $3 \mathrm{wk}$ before to $3 \mathrm{wk}$ after calving, when energy demand is increased due to the onset of lactation and many other hormonal changes (Grummer, 1995; Drackley, 1999; Duplessis et al., 2014b). Most cows experience negative energy balance (NEB) during this period, and genetics, physiology, management, and nutrition combine to determine the success of adaptation to NEB (Herdt, 2000; Ospina et al., 2013). Cows adapt to NEB 
by mobilizing fat reserves, which are oxidized to supply the Krebs cycle with partially oxidized fatty acids, generating ketone bodies, which spare glucose by serving as alternative fuel for some tissues (Grummer, 2008). Ketone production is a normal adaptation to NEB, but when excess amounts of ketones are produced and accumulate, this can contribute to adverse health effects (Duffield, 2000; Grummer, 2008). Excess ketone bodies and circulation of fatty acids from adipose tissue can increase the risk of fatty liver (Bobe et al., 2004; Schulz et al., 2014). Hyperketonemia (HYK) is a concentration of circulating ketone bodies associated with undesirable subsequent outcomes and is a costly problem in the dairy industry (McArt et al., 2015) because there is a loss of milk production and increased risk of diseases such as left displaced abomasum and metritis attributable to untreated HYK (Duffield, 2000; LeBlanc, 2010; Ospina et al., 2013) and because the cumulative incidence of HYK in early lactation is, on average, $>40 \%$ (McArt et al., 2012; Gordon et al., 2017a).

Dairy cattle are thought to be able to synthesize sufficient quantities of most $\mathrm{B}$ vitamins in the rumen to meet requirements for production of $35 \mathrm{~L} / \mathrm{d}$ of milk (NRC, 2001). Vitamin $B_{12}$ is necessary for the production of enzymes needed for methionine regeneration and methylmalonyl CoA mutase, which is needed for propionate to enter the Krebs cycle (Kennedy et al., 1990; Preynat et al., 2009a,b; Akins et al., 2013). Providing vitamin $B_{12}$ and folic acid together enhanced entry of propionate into Krebs cycle (Graulet et al., 2007; Preynat et al., 2009a), which may be beneficial because propionate is a major substrate for glucose synthesis in dairy cows (Danfær et al., 1995).

Several studies have investigated metabolic and production responses to increased dietary supply of B vitamins. Responses to supplemental B vitamins may vary with the availability of other methyl donors (e.g., dietary methionine or choline). Folates are used in the DNA cycle and the methylation cycle, and are necessary for reproduction and milk protein synthesis (Girard and Matte, 2005; Preynat et al., 2009a). Dietary supplementation of folate has led to increased milk yield, and the addition of dietary vitamin $\mathrm{B}_{12}$ has been shown to increase plasma glucose concentrations (Graulet et al., 2007). Providing supplemental folic acid and vitamin $\mathrm{B}_{12}$ by weekly injections increased milk production by $12 \%$ (Preynat et al., 2009a,b). However, in a field study of 805 cows in 15 herds (Duplessis et al., 2014a), weekly injections of folate and vitamin $B_{12}$ through the transition period generally did not affect health outcomes or milk yield, although milk protein percentage was increased (Duplessis et al., 2014b).

Choline is "quasi-vitamin" that, among other functions, is important in synthesis of phosphatidylcholine, a key part of the very-low density lipoprotein membranes for export of triglycerides from the liver. Dietary choline supplementation in cattle must be protected against degradation by rumen microbes. Numerous studies have investigated the effects of supplementation of rumen-protected choline in dairy cattle, with varied results. Several reported no effect of rumen-protected choline on liver fat content (Piepenbrink and Overton, 2003; Zahra et al., 2006), fatty acids or BHB concentrations (Zahra et al., 2006; Zom et al., 2011), or milk yield (Zom et al., 2011), whereas others found a positive milk yield response, especially among fat cows (Zahra et al., 2006).

The objective of this study was to measure the effect of a commercially available proprietary rumenprotected blend of $\mathrm{B}$ vitamins and choline (RPBC) on the incidence of health disorders, milk yield, and reproduction in early lactation in commercial dairy herds. We hypothesized that the supplementation of $\mathrm{B}$ vitamins and choline would reduce the incidence of HYK and decrease liver fat infiltration, which would consequently improve health and pregnancy rate and increase milk production in early lactation. Anecdotal reports suggested that the prevalence of udder edema might be reduced by this supplement, so udder edema was measured in the study.

\section{MATERIALS AND METHODS}

The University of Guelph Animal Care Committee reviewed and approved the study protocols that were accepted and followed by the herds enrolled.

\section{Experiment 1}

Study Size and Herds. The study was conducted on 3 commercial freestall dairy farms in Ontario, Canada, between November 2015 and December 2016. Herd size varied from 150 to 450 lactating cows. The herds are described in Table 1 . The primary outcome was the cumulative incidence of HYK (blood BHB $\geq 1.2$ mmol/L). Recent studies (McArt et al., 2012; Gordon et al., 2017a) have shown a mean cumulative incidence of $43 \%$ of HYK with testing of blood BHB concentration at least twice per cow, weekly, in the first 2 wk of lactation. To detect a reduction from 43 to $35 \%$ with $95 \%$ confidence and $80 \%$ power requires 1,166 cows (Abramson, 2011). For our secondary outcomes, that sample size would allow for detection of a $1 \mathrm{~kg} / \mathrm{d}(\mathrm{SD}=$ 6) difference in milk yield and a difference of 32 vs. $40 \%$ pregnancy at first AI. Herds were purposely selected based on milking at least 150 Holstein cows, being enrolled in DHI milk recording, maintaining accurate disease records, and accurate feed delivery. Herds enrolled 
agreed to provide supplementation according to the study protocol to cows from approximately $3 \mathrm{wk}$ before calving to $3 \mathrm{wk}$ after calving and not provide any other products that contained rumen-protected choline or B vitamins. The cows were fed a close-up diet for $3 \mathrm{wk}$ before their expected calving date and were transferred onto a fresh cow diet after calving. Each farm was visited weekly from November 2015 to December 2016. The nutrient content of the pre-fresh and milking cow TMR were analyzed at the beginning, middle, and end of each treatment period by a commercial laboratory (Agri-Food Laboratories, Guelph, Ontario, Canada). Diets are described in Table 2.

Treatment Delivery and Sample Collection. Data were collected weekly from each farm. Weekly copies of each farm's Dairy Comp 305 (Valley Ag Software, Tulare, CA) files were taken. The treatment consisted of $100 \mathrm{~g} /$ cow per d of a proprietary RPBC blend (Transition VB; Jefo, St. Hyacinthe, Quebec, Canada) containing $21 \%$ choline in addition to riboflavin, folic acid, $\mathrm{B}_{12}$, and vitamins $\mathrm{A}, \mathrm{D}_{3}$, and $\mathrm{E}$ microencapsulated in a lipid matrix. The placebo was an equal volume of a lipid supplement (Jefo Dairy Fat) with a similar consistency. To maintain blinding of the study participants and researchers, the products were delivered in generic $25-\mathrm{kg}$ bags labeled only as product $\mathrm{A}$ or $\mathrm{B}$. Herds were randomly assigned to feed either product A or product B in period 1 (November 2015 to May 2016), and after the first 6-mo period, switched to the other treatment for period 2 (June 2016 to December 2016). Producers were instructed to feed a dose of 100 $\mathrm{g}$ of product per head per day into the TMR or to top-dress to all close-up dry and early lactation cows. Cows were enrolled based on expected calving date at 3 wk before their due date and were started on the respective supplemental product. Cows were provided the product for $21 \mathrm{~d}$ after calving. Blood samples were collected from the coccygeal vessels into evacuated tubes without anticoagulant (Vacutainer; Becton, Dickinson and Company, Franklin Lakes, NJ) between 4 and 10 $\mathrm{d}$ before the expected calving date and between 1 and 7 DIM to measure serum fatty acids. Serum fatty acids were measured with a Cobas 6000 c501 (Roche, Basel, Switzerland) biochemistry analyzer using the Randox NEFA kit at the Animal Health Laboratory, University of Guelph. Blood samples were taken once each week for the first 3 wk postpartum to measure blood (BHB) with a validated point-of-care meter (Precision Xtra, Abbott Laboratories, Chicago, IL). Blood samples to measure serum progesterone were collected at wk 6 and 8 postpartum from the coccygeal vessels. Progesterone was measured using a validated (Broes and LeBlanc, 2014) ELISA kit (Ovucheck Plasma, Biovet) in our laboratory. Cows with serum progesterone $<1 \mathrm{ng} /$

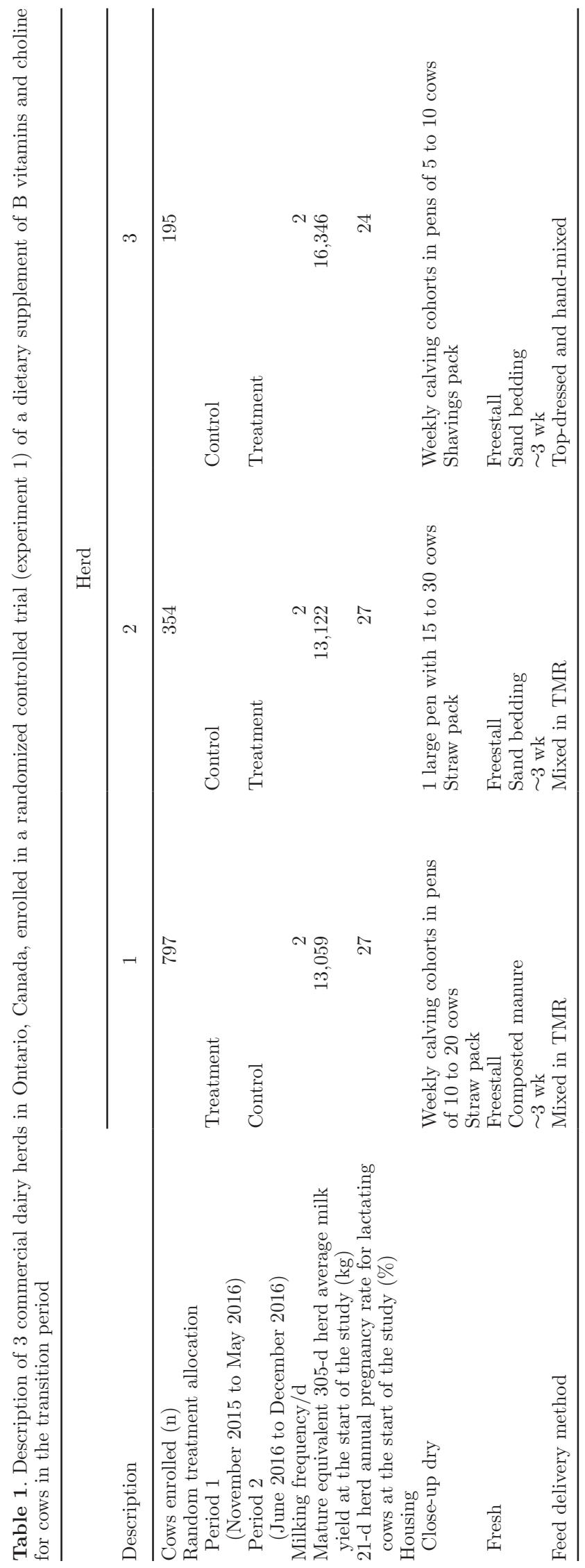


$\mathrm{mL}$ in both samples were classified as anovular. Body condition was scored on a 5-point scale (Edmonson et al., 1989) at enrollment (3 wk before calving) and at the end of treatment ( $3 \mathrm{wk}$ after calving). Cows were examined at wk 6 postpartum for purulent vaginal discharge using a Metricheck device (Simcrotech, Hamilton, New Zealand). Cows with muco-purulent or purulent discharge were classified as having purulent vaginal discharge. Udder edema was scored 0 to 3 based on a system developed for this study (Morrison et al., 2018), weekly from $1 \mathrm{wk}$ before calving and in the first 3 wk after calving. Scores were assigned based on visual assessment, as well as palpation of the udder.

Producers recorded the occurrence of milk fever (recumbence due to hypocalcemia), retained placenta ( $>24 \mathrm{~h}$ postpartum), metritis (fetid vulvar discharge with rectal temperature $>39.5 \mathrm{C}$ ), displaced abomasum (confirmed by a veterinarian during surgical correction), and clinical mastitis (visibly abnormal milk of any severity) $<30$ DIM according to standardized case definitions provided to them for the study. Reproductive management continued as per existing farm protocols (combination of estrus detection with activity monitors and synchronization for timed AI within each farm, and not different between treatments).

Statistical Analysis. A total of 1,346 cows were enrolled in the study, with 1,046 contributing complete data for all outcomes. Data were used from a total of 670 cows in the treatment group and 676 cows in the control group. Data collected over the study period were entered into Microsoft Excel (Microsoft Corporation, Redmond, WA). Data for diseases and reproductive performance were extracted from Dairy Comp 305 into Microsoft Excel. Producers did not record the dates of movement of cows between pens, but the amount of time on treatment before calving could be estimated from the date of the first weekly data collection ( $\mathrm{wk}-3$ BCS) and the calving date, plus an average of $3.5 \mathrm{~d}$, given weekly visits. Data for milk yield $(\mathrm{kg} / \mathrm{d}), \%$ fat, and $\%$ protein were accessed from DHIA for the first 3 test day samples for each cow from CanWest DHI (Guelph, Ontario, Canada). All statistical analyses were completed in SAS (version 9.4, SAS Institute Inc., Cary, NC). Significant differences were declared if $P<$ 0.05 and tendencies if $P<0.10$.

Mixed linear regression models (MIXED procedure in SAS) were used to evaluate continuous outcomes (milk production data, BHB and fatty acid concentrations) for the effects of treatment. Where relevant for blood BHB concentrations and milk yield, repeated measures were accounted for with an autoregressive type 1 covariance structure, selected based on providing the lowest Akaike's information criterion for the final model. Residuals for the models were graphically examined and variables with nonnormal distributions (BHB and fatty acids) had the outcome variable log-transformed for analysis. Univariable analysis of the association of treatment with categorical outcomes was done with chi-squared statistics before building models. Categorical clinical disease outcomes [BHB $\geq 1.2 \mathrm{mmol} / \mathrm{L}$ (after calving), fatty acids $\geq 0.4$ (the week before calving) and $\geq 0.7$ or $\geq 1.0$ (in wk 1 after calving), udder edema score $\geq 2$, and anovular status] were evaluated using logistic regression models (GLIMMIX procedure in SAS).

Time to event outcomes (intervals from calving to first AI, to pregnancy, and to culling $<30$ DIM) were evaluated using Kaplan-Meier estimates (LIFETEST procedure in SAS). Multivariable models employed Cox proportional hazard regression analysis (PHREG procedure in SAS). Cows sold for dairy purposes were not counted as culls within the first 30 DIM.

Each model was initially run with treatment, parity (first, second, or third or greater), farm, and all possible 2-way interactions with treatment as fixed effects and then reduced if the variables were not significant $(P>0.05)$. Initial assessment of the data included farm and the interaction of farm and treatment as a fixed effect. No farm or interaction of farm and treatment effects were present, and farm was thereafter modeled as a random effect. However, although all outcomes were assessed at the individual cow level, each farm had only one close-up dry and one fresh cow pen. Therefore, treatment was assigned at the pen level. To apply the correct error structure and degrees of freedom for treatment effects for this design (Bello et al., 2016), all final linear and logistic regression models included random effects of farm and the interaction of farm, treatment, and study period. Treatment means, SE, and $P$-values are reported from these analyses.

\section{Experiment 2}

Animals, Housing, and Management. The second experiment was conducted at the University of Guelph Elora Dairy Research Station (Elora, Ontario, Canada) in a freestall housing environment. The study was conducted between June and October 2016. Fifty multiparous and primiparous (33 and 17, respectively) Holstein cows were enrolled $25 \mathrm{~d}$ before their expected calving date and remained on the study until 9 wk postpartum. The sample size was based on detection of a difference of $5 \%$ points ( $\mathrm{SD}=6 \%$ points) of liver fat content, which required 23 cows per treatment. Each cow was randomly assigned to either RPBC or placebo, identical to experiment 1 . Treatments were balanced for parity and due date and researchers were blinded to the treatment assignments, which were delivered by facility personnel. 
Table 2. Descriptive summary of diets fed to herds 1 to 3 (experiment 1) in commercial herds in Ontario, Canada, and herd 4 (experiment 2) enrolled in a randomized controlled trial of a dietary supplement of rumen-protected B vitamins and choline for cows in the transition period ${ }^{1}$

Herd

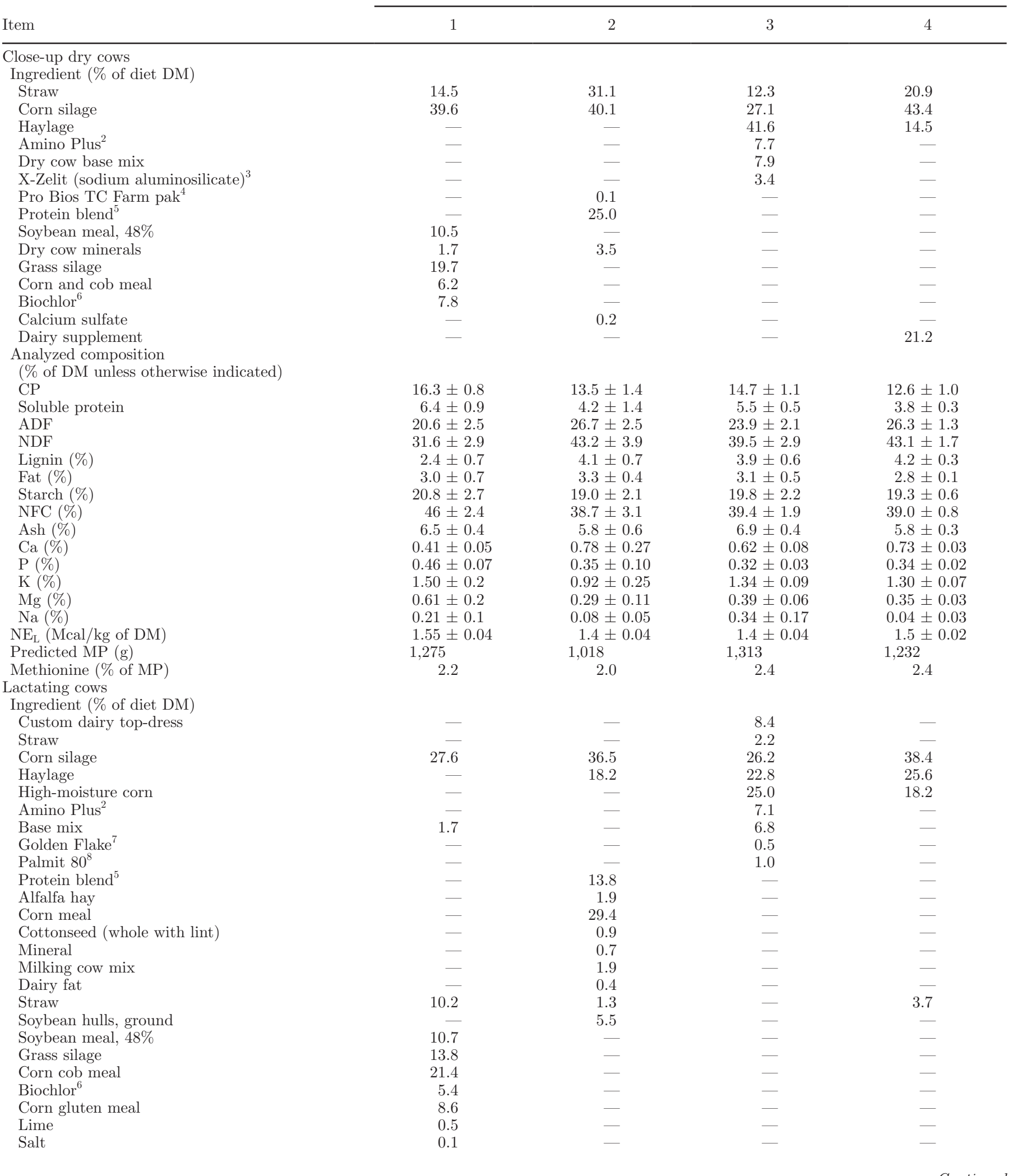


Table 2 (Continued). Descriptive summary of diets fed to herds 1 to 3 (experiment 1) in commercial herds in Ontario, Canada, and herd 4 (experiment 2) enrolled in a randomized controlled trial of a dietary supplement of rumen-protected B vitamins and choline for cows in the transition period $^{1}$

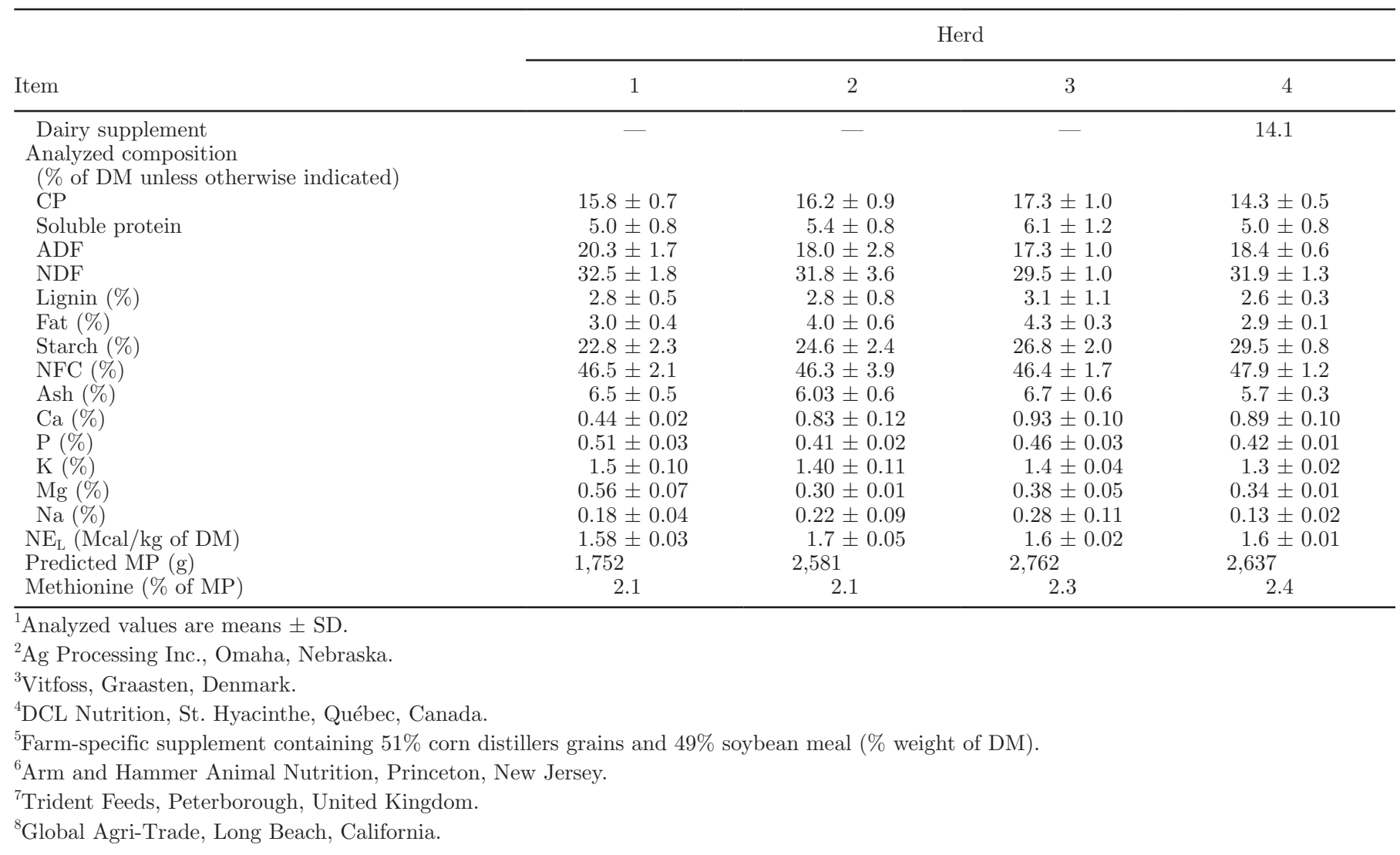

During the dry period cows were housed in 1 of 3 freestall pens with 12 Insentec (Hokofarm, Marnesse, the Netherlands) feeding bins with 1 cow assigned to 1 bin. At approximately $25 \mathrm{~d}$ prepartum, each cow was assigned and trained to an individual feed bin that was activated by their radio-frequency identification ear tag. During the course of the study all cows were fed a TMR once daily for ad libitum intake and daily feed intake (DFI) was recorded by the automated feed bins. Treatment was provided daily at feeding as a top dress, and hand mixed into the TMR. Weekly feed samples were collected to determine DM and nutrient content. The weekly samples were dried at $55^{\circ} \mathrm{C}$ for $24 \mathrm{~h}$ to determine DM percent, and the weekly samples were pooled by month and analyzed for nutrient content (Table 2).

At the first signs of calving or if calving was expected soon, cows were moved to individual maternity pens, where DFI continued to be recorded. Each cow remained in the maternity pen for 4 to $6 \mathrm{~d}$ postcalving, then was moved to 1 of 2 pens in the lactating barn. The lactating barn was also a freestall design, and each cow was individually assigned to 1 Insentec bin to which no other cows had access. Cows were fed
TMR once daily with their assigned treatment until 21 DIM and DFI was recorded. At 21 DIM the treatment was no longer fed, but DFI continued to be recorded for another $7 \mathrm{~d}$.

Blood Samples and Analysis. Blood samples were collected in the same manner as in experiment 1 , with the initial sample collected at 4 to $10 \mathrm{~d}$ prepartum (wk $-1)$, within $7 \mathrm{~d}$ postpartum $(\mathrm{wk}+1)$, then at wk 2,3 , 5,7 , and 9 postpartum. Blood samples were stored and analyzed in the same manner as in experiment 1 ; serum fatty acid concentration was analyzed at wk -1 and 1 , and blood BHB was analyzed cow side using a Precision Xtra device at wk 1, 2, and 3. Body score was also recorded at enrollment ( 3 wk prepartum) and at wk 5 .

Liver Biopsies and Analysis. Liver tissue was sampled via a puncture biopsy, at 3 to 5 (biopsy 1 ) and 13 to 15 (biopsy 2) DIM. The biopsy was performed while the cow was restrained in a standing chute, with mild sedation (20 mg of xylazine i.v.) used when necessary. The skin over the last 3 ribs on the right side at the level of the greater trochanter was shaved and disinfected using a 3-step surgical scrub with chlorhexidine gluconate (BD E-Z scrub preoperative scrub brush), $70 \%$ isopropyl alcohol (Commercial Alcohols, Bramp- 
ton, Ontario, Canada), and $10 \%$ povidone iodine solution. The skin and body wall were anesthetized with $10 \mathrm{~mL}$ of $2 \%$ lidocaine (Lidocaine Neat, Wyeth Animal Health, Guelph, Ontario, Canada). A stab incision was made through the skin in the area of the right 11th intercostal space where it crosses a line from the elbow to the tuber coxae at the level of the greater trochanter. A $30 \mathrm{~cm} \times 8 \mathrm{~mm}$ diameter biopsy trocar was passed through the incision, inserted into the liver, and approximately $2 \mathrm{~g}$ of liver tissue was collected. The skin incision was closed with $35 \mathrm{~mm}$ skin staples (3M Precise PGX Disposable Skin Stapler, London, Ontario, Canada). The liver sample was divided into 2 vials, with half flash frozen in liquid nitrogen then stored at $-80^{\circ} \mathrm{C}$ until analysis of fat content, and the other half preserved in Trizol (Thermo Fisher Scientific, Mississauga, Ontario, Canada) at $-80^{\circ} \mathrm{C}$ until analysis of RNA expression.

Transcriptome profile of genes from liver biopsies was performed at the Mammalian NutriPhysioGenomics laboratory, Department of Animal Sciences, University of Illinois according to procedures reported by Osorio et al. (2014). A list of the genes analyzed is reported in Supplemental Table S1 (https://doi.org/10.3168/ jds.2018-14663). This panel of genes was selected to represent aspects of energy and lipid metabolism that are relevant in peripartum dairy cows and might be affected directly or indirectly by the treatment.

Liver biopsies were analyzed for triacylglycerol (TAG) concentrations on a wet weight basis at the Mammalian NutriPhysioGenomics Laboratory, Department of Animal Sciences, University of Illinois. A total of $50 \mathrm{mg}$ of tissue was homogenized in $1.5 \mathrm{~mL}$ of PBS/10 m $M$ EDTA using a handheld homogenizer (Tissue-Tearor, Biospec Products, Bartlesville, OK). Subsequently, $200 \mu \mathrm{L}$ of GPBS-EDTA and $3 \mathrm{~mL}$ of isopropanol-hexane-water $(80: 20: 2 \mathrm{vol} / \mathrm{vol})$ were added to each sample and the mixture incubated covered with aluminum foil for $30 \mathrm{~min}$ at room temperature. One milliliter of hexane-diethyl ether (1:1) was then added to each sample followed by vortexing and incubation for $10 \mathrm{~min}$ at room temperature (protected from light). One milliliter of water was added to each sample to separate the lipid phase and the mixture was vortexed. Samples were incubated and covered with aluminum foil for $20 \mathrm{~min}$ at room temperature. The organic phase was then aspirated and placed into glass vials before evaporation under a stream of $\mathrm{N}$ gas. An 8-point TAG standard was prepared with Infinity TG reagent (Waltham, MA). Each sample was mixed with $540 \mu \mathrm{L}$ of Infinity TG reagent before vortexing. A total of $160 \mu \mathrm{L}$ of this sample mixture was pipetted into a flat-bottom 96 -well plastic microplate. The plate was incubated for $15 \mathrm{~min}$ at $37 \mathrm{C}$ before determining absorbance at 540 nm using a microplate reader. Concentration of TAG was calculated from the standard curve.

Statistical Analysis. All data were analyzed using SAS 9.4. Significant differences were declared if $P<$ 0.05 and tendencies if $P<0.10$. Average daily DMI and DHIA test-day milk yield were analyzed using mixed linear regression models (MIXED procedure of SAS), accounting for repeated measures with an autoregressive type 1 correction structure. The main effects of treatment and parity (primiparous or multiparous) and their interaction were analyzed. The test-day milk yield analysis additionally controlled for DIM and its quadratic term, test day, and milk fat and protein percentages, and a random effect of cows nested in treatment. Liver TAG concentrations were analyzed using mixed linear regression (MIXED procedure in SAS). Liver gene expression results were normalized to the geometric mean expression of 3 internal control genes and the real-time quantitative $\mathrm{PCR}$ data were $\log _{2}$ transformed to improve normality. Each gene was assayed in triplicate and the mean of the $3 \log _{2}$ transformed values was used for statistical analysis. Relative mRNA abundance among measured genes was calculated using the inverse of PCR efficiency raised to $\Delta \mathrm{Ct}$ (gene abundance $=$ $1 / \mathrm{E} \Delta \mathrm{Ct}$, where $\Delta \mathrm{Ct}=\mathrm{Ct}$ of tested gene - geometric mean $\mathrm{Ct}$ of 3 internal control genes); $\mathrm{Ct}$ of reference genes did not differ between treatments. Each gene was analyzed individually using the mixed linear regression (MIXED procedure in SAS), with the main effects of treatment, parity, time (biopsy 1 or 2), and their interactions considered in the model.

\section{RESULTS}

\section{Experiment 1}

On average, cows received the experimental diet supplement for at least $16 \mathrm{~d}(\mathrm{SD}=12 \mathrm{~d})$ before calving; $75 \%$ of the animals received treatment for $\geq 13 \mathrm{~d}$. Parity tended to differ $(P=0.08)$ between treatment $(2.3 \pm 0.06)$ and control $(2.5 \pm 0.06)$. Pre-treatment BCS was also similar $(P=0.48)$ for treatment $(3.7 \pm$ $0.01)$ and control $(3.6 \pm 0.01)$. Accounting for parity and initial BCS, there was no effect $(P=0.68)$ of treatment on BCS at 3 wk postcalving $(3.3 \pm 0.03$ in each group).

The timing of blood samples relative to calving was $($ mean $\pm \mathrm{SD})$, wk $-1:-3.4 \pm 2.7 \mathrm{~d}$; wk 1: $3.9 \pm 2.0 \mathrm{~d}$; wk 2: $10.7 \pm 2.2 \mathrm{~d}$; wk $3: 17.7 \pm 2.2$ d. No effect was observed of treatment on blood BHB $(P=0.85)$ concentrations overall (Table 3). The prevalence of HYK at each week (Table 3) and the cumulative incidence of HYK over 3 wk (29.7 and $28.0 \% ; P=0.52)$ did not differ between treatment and control, respectively. 
No effect was observed of treatment (vs. control) on the serum concentrations of fatty acids (mean $\pm \mathrm{SE}$ ) at wk $-1(0.24 \pm 1.32$ vs. $0.22 \pm 1.32 \mathrm{mmol} / \mathrm{L}, P=$ $0.55)$ or wk $1(0.71 \pm 1.06$ vs. $0.68 \pm 1.06, P=0.64)$. Categorized as the proportions of cows above cut points of fatty acid concentration for classification of disease risk, no difference was present between treatments: 21 $\pm 10 \%$ of cows $\geq 0.4 \mathrm{mmol} / \mathrm{L}$ at wk -1 in both groups $(P=0.98) ; 54 \pm 5$ vs. $48 \% \pm 5 \geq 0.7 \mathrm{mmol} / \mathrm{L}(P=$ $0.44)$, and $25 \pm 5$ vs. $23 \% \pm 5 \geq 1.0 \mathrm{mmol} / \mathrm{L}(P=$ $0.80)$ at wk 1 in treatment and control, respectively.

No effects were observed of treatment on the incidence of clinical disease or culling in early lactation (Table 4). The proportions of cows that experienced at least one clinical disease were not different $(P=$ 0.42 ) between treatment (25\%) and control (27\%). No difference was observed between treatments $(P=0.91)$ in udder edema scores or the proportions of cows with edema score $\geq 2(P=0.86)$, but edema decreased over time (Supplemental Table S2; https://doi.org/10.3168/ jds.2018-14663).

No difference $(P=0.52)$ was observed in the prevalence of anovulation at wk 8 postpartum between treatment $(11 \pm 9.6 \%)$ and control $(23 \pm 16.6 \%)$.

No difference was observed between treatments $(P$ $=0.15)$ in time to first AI: $63 \mathrm{~d}(95 \%$ CI, 60 to 65$)$ in treatment and $65 \mathrm{~d}(95 \% \mathrm{CI}, 63$ to 66$)$ in control. Accounting for parity, no difference $(P=0.83)$ was present in the proportion of cows pregnant at first $\mathrm{AI}$ in the treatment $(33 \pm 4.6 \%)$ and the control $(35 \pm 4.5 \%)$ group. Accordingly, no difference $(P=0.62)$ was present between treatment (97 d: 95\% CI, 92 to 104) and control (96 d: $95 \%$ CI 90 to 101) in time to pregnancy to 300 DIM.

Milk yield was based on data obtained from DHI for the first 3 test day samples and did not differ $(P=$ $0.56)$ between treatment $(43.8 \pm 3.7 \mathrm{~kg} / \mathrm{d})$ and control $(44.1 \pm 3.7 \mathrm{~kg} / \mathrm{d})$. No interaction of treatment by test day $(P=0.73)$ was observed in the model. The protein percentage was not different between treatments $(3.2 \pm$ $0.1 \%)$ and control $(3.2 \pm 0.1 \%)(P=0.36)$; a treatment by test day interaction $(P=0.01)$ was observed, with the only difference at test $\mathrm{d} 3(3.3 \pm 0.1 \%$ in RPBC and $3.2 \pm 0.1 \%, P=0.01)$. The overall protein yield was not different $(P=0.78)$ between treatment $(1.4 \pm$ $0.11 \mathrm{~kg} / \mathrm{d})$ and control $(1.4 \pm 0.11 \mathrm{~kg} / \mathrm{d})$, and no treatment by test day interaction $(P=0.15)$ was observed. The overall milk fat percentage was not different $(P$ $=0.38)$ between treatment $(4.1 \pm 0.18 \%)$ and control $(4.0 \pm 0.18 \%)$; a treatment by test day interaction $(P=$ $0.02)$ was observed with a tendency for difference only at test $\mathrm{d} 2(4.0 \pm 0.2 \%$ in RPBC and $3.9 \pm 0.2 \%, P=$ $0.08)$. Test day milk fat yield did not differ $(1.79 \pm 0.23$ in $\mathrm{RPBC}$ and $1.75 \pm 0.23 \mathrm{~kg}, P=0.46)$, and despite a

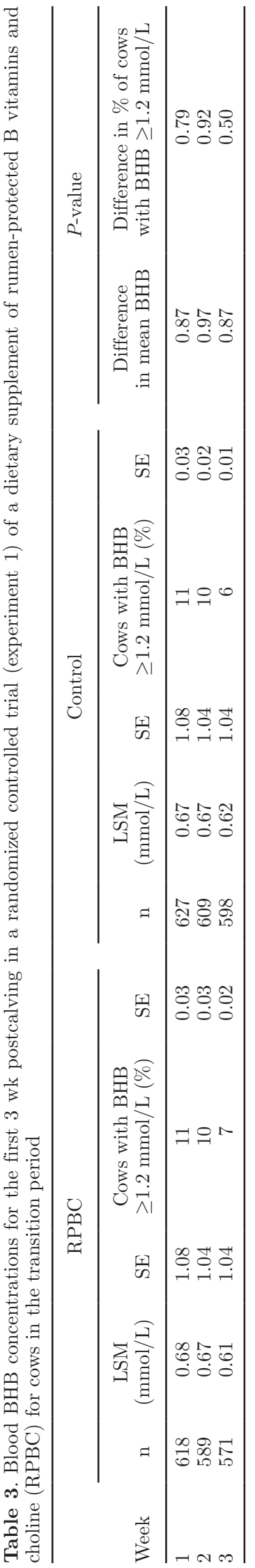

Journal of Dairy Science Vol. 101 No. 10, 2018 
Table 4. Clinical disease incidence in a randomized controlled trial (experiment 1) of a dietary supplement of rumen-protected $\mathrm{B}$ vitamins and choline (RPBC) for cows in the transition period

\begin{tabular}{|c|c|c|c|}
\hline \multirow[b]{2}{*}{ Clinical disease } & \multicolumn{2}{|c|}{ Incidence risk (\%) } & \multirow[b]{2}{*}{$P$-value } \\
\hline & $\begin{array}{c}\mathrm{RPBC} \\
(\mathrm{n}=670)\end{array}$ & $\begin{array}{c}\text { Control } \\
(\mathrm{n}=676)\end{array}$ & \\
\hline Retained placenta & 6.3 & 4.5 & 0.26 \\
\hline Milk fever & 0.9 & 1.8 & 0.52 \\
\hline Metritis & 0.5 & 1.3 & 0.56 \\
\hline Displaced abomasum & 1.5 & 2.5 & 0.28 \\
\hline First case of clinical mastitis $<30$ DIM & 2.4 & 1.9 & 0.75 \\
\hline Early cull $^{1}$ & 4.3 & 2.2 & 0.13 \\
\hline Purulent vaginal discharge ${ }^{2}$ & 14.3 & 19.5 & 0.48 \\
\hline
\end{tabular}

${ }^{1}$ Sold or died within the first 30 DIM excluding sales as dairy cows/exports.

${ }^{2} \mathrm{n}=535$ for treatment and $\mathrm{n}=556$ for the control.

treatment by test day interaction $(P=0.01)$, fat yields did not differ at any of test $\mathrm{d} 1,2$, or 3 (maximum difference of $0.09 \pm 0.06 \mathrm{~kg}, P \geq 0.11$ ).

\section{Experiment 2}

On average, cows received the experimental diet supplement for $25 \mathrm{~d}$ (SD $=6 \mathrm{~d}$ ) before calving; $75 \%$ of the animals received treatment for $\geq 22 \mathrm{~d}$.

No differences were observed between treatments in DMI before or after calving (Table 5). Accounting for parity, DIM, fat and protein percentages, and repeated test days, milk yield did not differ significantly between treatments across the first 3 DHIA tests $(41.2 \pm 1.3$ in RPBC vs. $38.0 \pm 1.4 \mathrm{~kg} / \mathrm{d}$ in control, $P=0.11)$. No treatment by test day interaction $(P=0.97)$ was observed, and the increment $(P=0.14$ to 0.16$)$ of test-day milk yield between treatments was consistent among test days. Modeled as above, milk components did not differ between treatments across the first 3 DHIA test days: fat, $4.0 \pm 0.1 \%$ in RPBC vs. $4.1 \pm 0.1 \%$ in control, $P=0.62$; protein, $3.0 \pm 0.03 \%$ in RPBC vs. $3.0 \pm$ $0.03 \%$ in control, $P=0.47$.

The timing of blood samples relative to calving was (mean \pm SD), wk $-1:-3.3 \pm 2.2$ d; wk 1: $2.6 \pm 0.9$ d; wk 2: $10.7 \pm 1.9$ d; wk 3: $17.7 \pm 2.0$ d. Mean blood BHB was lower at wk 3 in RPBC (Supplemental Table
S3; https://doi.org/10.3168/jds.2018-14663) with no difference between treatments for mean blood concentrations of fatty acids (wk -1 or 1 ) and BHB at wk 1 or 2 . An interaction was observed of treatment with parity for mean BHB $(P=0.02)$, but when stratified, no significant differences were observed in back-transformed least squares mean BHB concentrations: primiparous, $0.52 \mathrm{mmol} / \mathrm{L}$ in $\mathrm{RPBC}$ and $0.55 \mathrm{mmol} / \mathrm{L}$ in control, $P=0.70 ;$ multiparous, $0.87 \mathrm{mmol} / \mathrm{L}$ in $\mathrm{RPBC}$ and $1.01 \mathrm{mmol} / \mathrm{L}$ in control, $P=0.20$. No interaction was observed of treatment with parity $(P=0.50)$ for mean fatty acid concentration. The proportions of cows with BHB $\geq 1.2 \mathrm{mmol} / \mathrm{L}$ at each of wk 1,2 , and 3 were not different $(P>0.65)$ between treatments $(8,13$, and $20 \%$ in RPBC, and 10, 15, and $25 \%$ in control, respectively). The cumulative incidence of HYK over 3 wk was $46 \%$ in $\mathrm{RPBC}$ and $42 \%$ in control $(P=0.77)$. The proportions of cows with fatty acids $\geq 0.4 \mathrm{mmol} / \mathrm{L}$ in wk -1 (21 vs. $14 \%, P=0.57$ ) or $>0.7 \mathrm{mmol} / \mathrm{L}$ in wk 1 (52 vs. $54 \%$, $P=0.88)$ did not differ between groups. Treatment did not affect liver TAG in multiparous cows (Table 6). In primiparous cows, liver TAG was lower at 4 DIM in RPBC but not at 14 DIM (Table 6). One gene in liver tissue was differentially expressed between treatments: $A C O X 1$, an indicator of oxidation of long-chain fatty acids, had lower expression at both time points in the treatment group (Supplemental Table S4; https://doi

Table 5. Feed intake (DMI, $\mathrm{kg} / \mathrm{d}$ ) accounting for pretreatment BCS and parity in a randomized controlled trial of a dietary supplement of rumen-protected B vitamins and choline (RPBC) for cows in the transition period (experiment 2$)^{1}$

\begin{tabular}{|c|c|c|c|c|}
\hline \multirow[b]{2}{*}{ Time period } & \multicolumn{2}{|c|}{ Treatment } & \multirow[b]{2}{*}{ SEM } & \multirow[b]{2}{*}{$P$-value } \\
\hline & $\mathrm{RPBC}$ & Control & & \\
\hline Treatment: dry; 21 d prepartum & 13.7 & 13.4 & 0.53 & 0.27 \\
\hline Treatment: lactation; 1 to 21 DIM & 14.6 & 13.9 & 0.70 & 0.33 \\
\hline Posttreatment: 22 to 28 DIM & 17.9 & 16.9 & 0.74 & 0.19 \\
\hline
\end{tabular}

${ }^{1}$ Cows with displaced abomasum $(n=2)$ or metritis $(n=1)$ were removed from the analysis. 
Table 6. Liver triacylglycerol (TAG) concentration ( $\mathrm{mg}$ of $\mathrm{TAG} / \mathrm{g}$ of wet tissue weight) accounting for pretreatment BCS in a randomized controlled trial (experiment 2) of a dietary supplement of rumen-protected $\mathrm{B}$ vitamins and choline (RPBC) for cows in the transition period

\begin{tabular}{lcccc}
\hline & \multicolumn{2}{c}{ Treatment } & & \\
\cline { 2 - 3 } Item & RPBC & Control & SEM & $P$-value \\
\hline Liver TAG (\%) & 3.4 & 4.4 & 0.74 & 0.17 \\
Biopsy 1 (3 to 5 DIM) & 3.4 & 3.9 & 0.62 & 0.45 \\
Biopsy 2 (13 to 15 DIM) & & & & \\
Liver TAG $\times$ parity (\%) & 2.0 & 4.4 & 1.20 & 0.05 \\
Biopsy 1 primiparous & 4.8 & 4.4 & 0.87 & 0.76 \\
Biopsy 1 multiparous & 2.2 & 3.2 & 0.97 & 0.34 \\
Biopsy 2 primiparous & 4.6 & 4.6 & 0.76 & 0.99 \\
Biopsy 2 multiparous & & & & \\
\hline
\end{tabular}

.org/10.3168/jds.2018-14663). Several differences were observed in gene expression over time but no treatment by time or treatment by parity interactions.

\section{DISCUSSION}

In experiment 1 , the hypothesized effects of the RPBC blend during the transition period on HYK, clinical diseases, milk yield, and reproductive performance were not observed. The 3 commercial herds employed typical management practices of close-up dry cows including weekly movements of new cows into the pens. However, this resulted in one-quarter of the cows receiving the dietary treatment for only $2 \mathrm{wk}$, shorter than the $3 \mathrm{wk}$ suggested by the manufacturer of the RPBC product, which might have diminished its effect.

The cumulative incidence of HYK in the first $3 \mathrm{wk}$ postpartum in experiment 1 was $29 \%$, which did not differ between treatment groups. The median duration of untreated HYK is 5 d (McArt et al., 2011), so sampling weekly to detect HYK may underestimate the true incidence, albeit equally between treatments [McArt et al. (2014) estimated the sensitivity would be $71 \%$ if testing once weekly starting at 3 DIM]. This incidence is lower than other studies in the same region using the same weekly sampling, where the cumulative herd incidence was $43 \%$ and the herd incidence ranged from 20 to $79 \%$ (Gordon et al., 2017a,b). Ospina et al. (2010) found a lower herd-level incidence of HYK (15 to 20\%) compared with the aforementioned studies. The herds in the present study had high production, good reproduction, and low incidences of disease. On one hand, high-producing cows might have physiologic demands and therefore nutrient requirements that might be more responsive to supplemental supply of choline and B vitamins. Conversely, the incidence of HYK worked against our hypothesis and may have reduced the opportunity to demonstrate a treatment effect.
The results of the present study suggested a lower prevalence of anovular cows (11\% in RPBC and $23 \%$ in control), but no statistical difference was observed between treatments and no difference was observed in pregnancy at first AI. Accounting for pen-level delivery of the treatment reduced the statistical power to establish a treatment effect on the prevalence of anovular condition, but an effect of this magnitude, if present, would be of interest, so this outcome should be assessed in future studies with the supplement delivered to individual animals.

By design, no supplemented rumen-protected methionine was provided in this study. The predicted supply of methionine ( 2.1 to $2.3 \%$ of MP) in the herds in experiment 1 was likely adequate $(>2.06 \%$ of $\mathrm{MP})$ according to the assumptions and calculations of NRC (2001) but suboptimal for milk protein yield, whereas the estimated supply of methionine in experiment 2 (2.4\% of MP) meets the requirement proposed by NRC based on milk protein yield responses. Other studies (Preynat et al., 2009a,b, 2010) provided 93\% of NRC requirement of dietary methionine by supplementing the basal diet with rumen-protected methionine along with supplemental B vitamins as part of the experimental treatment. If the supply of methionine in the diets was sufficient, that might allow the $\mathrm{B}$ vitamins and choline in the RPBC supplement to be used other than as methyl donors; in particular vitamin $\mathrm{B}_{12}$ might be employed as a co-enzyme for propionate to enter the Krebs cycle and thereby to contribute to subsequent gluconeogenesis (Preynat et al., 2009a). However, we generally did not observe changes in the metabolic markers measured in blood or in milk yield that would be hypothesized if gluconeogenesis were improved.

By feeding groups of cows with TMR, the consumption of supplement may have varied by day or among cows, although this reflects feeding in commercial herds. Studies by Preynat et al. (2009b) and Duplessis et al. (2014b) administered injectable B vitamins, 
which allowed for control of delivery throughout the study. That removes some sources of variation. Further research on the metabolism of dietary $\mathrm{B}$ vitamin in the rumen may be helpful to tailor supplementation in the context of differences among diets.

In experiment 2, we did not observe benefits of RPBC on feed intake or (with one exception) on expression of a panel of hepatic genes chosen to represent key elements of metabolic pathways relevant to dairy cows in the transition period. We did detect lower mean blood BHB at wk 3 postpartum only, and a lower degree of liver fat infiltration in RPBC among primiparous cows at 4 DIM. A similar magnitude of reduction in mean BHB, specifically at wk 2 postpartum, was observed in a field case study with a RPBC supplement (Evans et al., 2006b). We note that DMI was high in the close-up dry cows, and liver fat percentages were low. Bobe et al. (2004) propose that 5\% liver TAG indicates moderate fatty liver, and on average, both groups were below that level at both time points sampled, including at the second biopsy at 13 to 15 DIM when liver fat infiltration is expected to be near maximal. The one hepatic gene differentially expressed between treatment groups, acyl-CoA oxidase 1 ( $A C O X 1$ ), had lower abundance in cows that received $\mathrm{RPBC}$ at both biopsies. This gene codes for an enzyme that begins the process of breakdown of long-chain fatty acids in the peroxisomal fatty acid $\beta$-oxidation pathway. If mobilization of adipose were similar (no differences in serum fatty acid concentrations observed in either experiment), a lesser rate of oxidation of fatty acids might be expected to lead to greater ketogenesis or accumulation of TAG in the liver (neither of which was observed here), which does not fit with the observation of lower liver TAG in primiparous cows at 4 DIM. Nevertheless, the modest difference in BHB concentrations at wk 3 and the difference in liver TAG in primiparous animals encourage further work to identify the diet or management conditions or mechanisms by which RPBC may improve metabolic status or performance.

Girard and Matte (1998) and Graulet et al. (2007) found increases in milk yield of $6 \%$ and $3.4 \mathrm{~kg} / \mathrm{d}$ respectively with supplementation of B vitamins from 4 wk prepartum to 305 DIM and 3 wk prepartum to 8 wk postpartum, respectively. Sacadura et al. (2008) found that cows receiving a rumen-protected B vitamin supplement produced $0.9 \mathrm{~kg} / \mathrm{d}$ more milk in early lactation and $0.03 \mathrm{~kg} / \mathrm{d}$ more milk protein compared with control cows. Conversely, as in the present study, a field case study (Evans et al., 2006a), including a group supplemented with a different RPBC in the transition period only, did not observe a difference in milk yield.

\section{CONCLUSIONS}

Under the conditions of this study, including a low incidence of HYK and clinical disease, the supplementation of a complex of rumen-protected B vitamins and choline to transition cows in a large multi-herd trial under field conditions did not have an effect on the incidence of HYK, clinical health disorders, milk yield, or reproductive performance. In an experiment in a research herd, primiparous cows had lower liver fat content postpartum. Future research should quantify the herd conditions under which supplementation of choline and B vitamins may provide benefits to health or productivity.

\section{ACKNOWLEDGMENTS}

We thank Jefo for the financial support of this research project. Funding was also provided by a Collaborative Research and Development grant from the Natural Science and Engineering Research Council of Canada (NSERC). We gratefully acknowledge the expert assistance of Juan Loor and the Mammalian NutriPhysioGenomics Laboratory, Department of Animal Sciences, University of Illinois (Urbana-Champaign) for the liver fat and gene expression analyses. We also thank the staff at the Elora Dairy Livestock Research and Innovation Centre for their assistance with this project.

\section{REFERENCES}

Abramson, J. H. 2011. WINPEPI updated: Computer programs for epidemiologists, and their teaching potential. Epidemiol. Perspect. Innov. 8:1.

Abuajamieh, M., S. K. Kvidera, M. V. Sanz Fernandez, A. Nayeri, N. C. Upah, E. A. Nolan, S. M. Lei, J. M. DeFrain, H. B. Green, K. M. Schoenberg, W. E. Trout, and L. H. Baumgard. 2016. Inflammatory biomarkers are associated with ketosis in periparturient Holstein cows. Res. Vet. Sci. 109:81-85.

Akins, M. S., S. J. Bertics, M. T. Socha, and R. D. Shaver. 2013. Effects of cobalt supplementation and vitamin B12 injections on lactation performance and metabolism of Holstein dairy cows. J. Dairy Sci. 96:1755-1768.

Bello, N. M., M. Kramer, R. J. Tempelman, W. W. Stroup, N. R. St-Pierre, B. A. Craig, L. J. Young, and E. E. Gbur. 2016. Short communication: On recognising the proper experimental unit in animal studies in the dairy sciences. J. Dairy Sci. 99:8871-8879.

Bobe, G., J. W. Young, and D. C. Beitz. 2004. Invited review: Pathology, etiology, prevention, and treatment of fatty liver in dairy cows. J. Dairy Sci. 87:3105-3124.

Broes, A., and S. J. LeBlanc. 2014. Comparison of commercial progesterone assays for evaluation of luteal status in dairy cows. Can. Vet. J. 55:582-584.

Danfær, A., V. Tetens, and N. Agergaard. 1995. Review and an experimental study on the physiological and quantitative aspects of gluconeogenesis in lactating ruminants. Comp. Biochem. Physiol. B Biochem. Mol. Biol. 111:201-210. 
Drackley, J. K. 1999. Biology of dairy cows during the transition period: The final frontier? J. Dairy Sci. 82:2259-2273.

Duffield, T. 2000. Subclinical ketosis in lactating dairy cattle. Vet. Clin. North Am. Food Anim. Pract. 16:231-253.

Duplessis, M., C. L. Girard, D. E. Santschi, J. P. Laforest, J. Durocher, and D. Pellerin. 2014a. Effects of folic acid and vitamin B12 supplementation on culling rate, diseases and reproduction in commercial dairy herds. J. Dairy Sci. 97:2346-2354.

Duplessis, M., C. L. Girard, D. E. Santschi, D. M. Lefebvre, and D. Pellerin. 2014b. Milk production and composition, and body measurements of dairy cows receiving intramuscular injections of folic acid and vitamin B-12 in commercial dairy herds. Livest. Sci. 167:186-194.

Edmonson, A. J., I. J. Lean, L. D. Weaver, T. Farver, and G. Webster. 1989. A body condition scoring chart for Holstein dairy cows. J. Dairy Sci. 72:68-78.

Evans, E., D. T. Mair, R. Gauthier, and J. Fontaine. 2006a. Case study: Effects of providing a protected vitamin and choline supplement in the transition period on dairy cow production and reproduction. Prof. Anim. Sci. 22:158-163.

Evans, E., D. T. Mair, R. Gauthier, and J. Fontaine. 2006b. Case study: Effects of a protected vitamin and choline supplement in the transition period on dairy cow metabolic parameters and health. Prof. Anim. Sci. 22:164-169.

Girard, C. L., and J. J. Matte. 1998. Dietary supplements of folic acid during lactation: Effects on the performance of dairy cows. J. Dairy Sci. 81:1412-1419.

Girard, C. L., and J. J. Matte. 2005. Effects of intramuscular injections of vitamin B12 on lactation performance of dairy cows fed dietary supplements of folic acid and rumen-protected methionine. J. Dairy Sci. 88:671-676.

Gordon, J. L., T. F. Duffield, T. H. Herdt, D. F. Kelton, L. Neuder, and S. J. LeBlanc. 2017a. Effects of a combination butaphosphan and cyanocobalamin product and insulin on ketosis resolution and milk production. J. Dairy Sci. 100:2954-2966.

Gordon, J. L., S. J. LeBlanc, D. F. Kelton, T. H. Herdt, L. Neuder, and T. F. Duffield. 2017b. Randomized clinical field trial on the effects of butophosphan-cyanocobalamin and propylene glycol on ketosis resolution and milk production. J. Dairy Sci. 100:3912-3921.

Graulet, B., J. J. Matte, A. Desrochers, L. Doepel, M. F. Palin, and C. L. Girard. 2007. Effects of dietary supplements of folic acid and vitamin B12 on metabolism of dairy cows in early lactation. J. Dairy Sci. 90:3442-3455.

Grummer, R. R. 1995. Impact of changes in organic nutrient metabolism on feeding the transition dairy cow. J. Anim. Sci. 73:28202833.

Grummer, R. R. 2008. Nutritional and management strategies for the prevention of fatty liver in dairy cattle. Vet. J. 176:10-20.

Herdt, T. H. 2000. Ruminant adaptation to negative energy balance. Influences on the etiology of ketosis and fatty liver. Vet. Clin. North Am. Food Anim. Pract. 16:215-230.

Kennedy, D. G., A. Cannavan, A. Molloy, F. O. Harte, S. M. Taylor, S. Kennedy, and W. J. Blanchflower. 1990. Methylmalonyl-CoA mutase (EC 5.4.99.2) and methionine synthetase (EC 2.1.1.13) in the tissues of cobalt-vitamin B12 deficient sheep. Br. J. Nutr. 64:721-732.

LeBlanc, S. 2010. Monitoring metabolic health of dairy cattle in the transition period. J. Reprod. Dev. 56:S29-S35.

McArt, J. A. A., D. V. Nydam, and G. R. Oetzel. 2012. Epidemiology of subclinical ketosis in early lactation dairy cattle. J. Dairy Sci. 95:5056-5066.

McArt, J. A. A., D. V. Nydam, G. R. Oetzel, and C. L. Guard. 2014. An economic analysis of hyperketonemia testing and propylene glycol treatment strategies in early lactation dairy cattle. Prev. Vet. Med. 117:170-179.
McArt, J. A. A., D. V. Nydam, P. A. Ospina, and G. R. Oetzel. 2011. A field trial on the effect of propylene glycol on milk yield and resolution of ketosis in fresh cows diagnosed with subclinical ketosis. J. Dairy Sci. 94:6011-6020.

McArt, J. A. A., D. V. Nydam, and M. W. Overton. 2015. Hyperketonemia in early lactation dairy cattle: A deterministic estimate of component and total cost per case. J. Dairy Sci. 98:2043-2054.

Morrison, E., T. DeVries, and S. LeBlanc. 2018. Short communication: Associations of udder edema with health, milk yield, and reproduction in dairy cows in early lactation. J. Dairy Sci. 101:95219526. https://doi.org/10.3168/jds.2018-14539.

NRC. 2001. Nutrient Requirements of Dairy Cattle. National Academy of Sciences, Washington, DC.

Osorio, J. S., P. Ji, J. K. Drackley, D. Luchini, and J. J. Loor. 2014. Smartamine M and MetaSmart supplementation during the peripartal period alter hepatic expression of gene networks in 1-carbon metabolism, inflammation, oxidative stress, and the growth hormone-insulin-like growth factor 1 axis pathways. J. Dairy Sci. 97:7451-7464.

Ospina, P. A., J. A. McArt, T. R. Overton, T. Stokol, and D. V. Nydam. 2013. Using nonesterified fatty acids and $\beta$-hydroxybutyrate concentrations during the transition period for herd-level monitoring of increased risk of disease and decreased reproductive and milking performance. Vet. Clin. North Am. Food Anim. Pract. $29: 387-412$

Ospina, P. A., D. V. Nydam, Y. Stokol, and T. R. Overton. 2010. Association between the proportion of sampled transition cows with increased nonesterified fatty acids and $\beta$-hydroxybutyrate and disease incidence, pregnancy rate, and milk production at herd level. J. Dairy Sci. 93:3595-3601.

Piepenbrink, M. S., and T. R. Overton. 2003. Liver metabolism and production of cows fed increasing amounts of rumen-protected choline during the periparturient period. J. Dairy Sci. 86:1722-1733.

Preynat, A., H. Lapierre, M. C. Thivierge, M. F. Palin, N. Cardinault, J. J. Matte, A. Desrochers, and C. L. Girard. 2010. Effects of supplementary folic acid and vitamin B12 on hepatic metabolism of dairy cows according to methionine supply. J. Dairy Sci. 93:2130-2142.

Preynat, A., H. Lapierre, M. C. Thivierge, M. F. Palin, J. J. Matte, A. Desrochers, and C. L. Girard. 2009a. Effects of supplements of folic acid, vitamin B12, and rumen-protected methionine on whole body metabolism of methionine and glucose in lactating dairy cows. J. Dairy Sci. 92:677-689.

Preynat, A., H. Lapierre, M. C. Thivierge, M. F. Palin, J. J. Matte, A. Desrochers, and C. L. Girard. 2009b. Influence of methionine supply on the response of lactational performance of dairy cows to supplementary folic acid and vitamin B12. J. Dairy Sci. 92:16851695.

Sacadura, F. C., P. H. Robinson, E. Evans, and M. Lordelo. 2008. Effects of a ruminally protected B-vitamin supplement on milk yield and composition of lactating dairy cows. Anim. Feed Sci. Technol. 144:111-124.

Schulz, K., J. Frahm, U. Meyer, S. Kersten, D. Reiche, J. Rehage, and S. Dänicke. 2014. Effects of prepartal body condition score and peripartal energy supple of dairy cows on postpartal lipolysis, energy balance and ketogenesis: an animal model to investigate subclinical ketosis. J. Dairy Res. 81:257-266.

Zahra, L. C., T. F. Duffield, K. E. Leslie, T. R. Overton, D. Putnam, and S. J. LeBlanc. 2006. Effects of rumen-protected choline and monensin on milk production and metabolism of periparturient dairy cows. J. Dairy Sci. 89:4808-4818.

Zom, R. L. G., J. van Baal, R. M. A. Goselink, J. A. Bakker, M. J. de Veth, and A. M. van Vuuren. 2011. Effect of rumen-protected choline on performance, blood metabolites and hepatic triacylglycerols of periparturient dairy cattle. J. Dairy Sci. 94:4016-4027. 